\begin{tabular}{|c|c|c|}
\hline Received: May 2018 & Accepted: October 2018 & Published: October 2018 \\
\hline \multicolumn{2}{|c|}{ Article DOI: http://dx.doi.org/10.24903/sj.v3i2.212 } \\
\hline
\end{tabular}

\title{
Edmodo as Educational Social Network in Teaching Course Design of EYL
}

\author{
Nina Puspitaloka \\ Universitas Singaperbangsa Karawang \\ nina.puspitaloka@fkip.unsika.ac.id \\ Indah Rachmawati \\ Universitas Singaperbangsa Karawang \\ indahrahmawati4528@gmail.com \\ Derinda Octaviyenty Sonjaya \\ Universitas Singaperbangsa Karawang \\ derindaoctaviyenty67@gmail.com
}

\begin{abstract}
This research is conducted to find out Edmodo can increase student's ability in learning course design of EYL and student's perception in learning course design of EYL by using Edmodo. A mixed method was used to collect quantitative and qualitative data. In answering those two research questions, the researcher used test (pre-test and post-test) to collect quantitative data and also used interview as data gathering technique to collect qualitative data. The findings of the research showed that: (1) Edmodo can increase student's ability in learning course design of EYL. It is proven by the score of Independent T-test -0,741 and sig (2 tailed) was higher than degree of significance $(0,462<0,05)$. (2) Student's perception in learning course design of EYL by using Edmodo showed that Edmodo in learning course design of EYL can help students more understand the materials because they can get more information about materials of EYL especially course design of EYL; they can discuss the materials each other anywhere and anytime; they felt more interesting and happy; they are more confident to express their ideas, therefore they can be more active in learning course design of EYL..
\end{abstract}

Keywords: Edmodo, Course Design of EYL. 


\section{INTRODUCTION}

Course Design of EYL is the elective course that must be taken by the students at the fifth semester in English Education Department of Unsika. This course explained lesson plan, learning strategies and techniques to teach English for young learners. As we already know that teaching Course Design of EYL by using lecturing method, make students lack of motivation, bored, sleepy, and low confident. Therefore, the researchers applied Edmodo as mediated to teach Course Design of EYL. Edmodo is one of the important media can help the students to understand the material in the classroom, especially Course Design of EYL. Edmodo is a solution to help the teacher in conveying and explaning the materials in modern way that more fun and interesting. One of the modern ways to convey and explain the material can be use flipped classroom technique which moving traditional learning to modern. Bergmann and Sams in Basal (2015: 2) argue that: a flipped classroom can be described as a setting where that "which is traditionally done in class is now done at home, and that which is traditionally done as homework is now completed in class". Using flipped classroom technique, the students will get the material before they come to the class and it needs a modern media which utilize educational social network. It called Edmodo. Edmodo is an application that designed in education system.

"Edmodo is global education network that helps connect all learners with the people and resources needed to reach their full potential" (www.Edmodo.com). In other word, Edmodo is a full featured social learning platform designed to connect and collaborate within the educational environment. Edmodo is easily installed on computers, laptops and android. It is the social media network which collaborates and connect, share content and get access homework, school notices and grades. The teachers use Edmodo as an online blackboard and inbox to post polls, quizzes, and assignment guidelines and invite student to submit finished assignment (Evenddy and Hamer, 2016). For the student, edmodo can collaborate their project, asking questions and working together.

Cauley (2013) from "A guide to Explain it all” (IT Babble.com) in Monalisa and Ardi (2013, p.221) stated that one of the educational website that takes the ideas of social network and makes it appropriate for a classroom is Edmodo. Edmodo helps students and teachers to connect one and another by sharing ideas, problem, and useful tips. By using Edmodo, students can get help from the entire class, and teachers can assign and grade work. In addition, Edmodo allows parents to join and to check the progress in a study of their 
children. Inappropriate content and spam cannot reach Edmodo because teachers can identify everything that is posted on Edmodo.

Giving and submitting assignments can be held virtually. Student's score can be recorded by teachers. Meanwhile, students and parents have accessibility to check student's progress in study. By using Edmodo, teachers are also able to provide quiz, polling, and post topic for discussion among students (Thompson, 2013).

Edmodo provides the ability for students to present and to post their assignment because space for place student work is also provided. All grades and badges that the students get are accessible for the teachers, the parents and the students themselves.

Course Design of EYL is a course that given in the English Education Department Unsika. This course aims to develop the knowledge and practical skills which are required to teach English to young learners effectively. According to Graves (2000), the course development process involves defining the context, articulating beliefs, conceptualizing content, formulating goals and objectives, assessing needs, organizing the course, developing materials and designing an assessment plan.

Teaching English for Young Learner (EYL) is guiding and facilitating students of 512 years old about their activities in learning, understanding, knowing and comprehending ideas, attitude, skills and information of English as a foreign language learners (Prasetya, 2011). Therefore, in teaching EYL, teacher should has strategy and creativity in making fun and enjoyed learning situation. According to Suyanto (2007), the characteristic of young learner are egocentric, imaginative, active and cheerful. Thus, Course Design of EYL is very needed to teach English for young learner.

It provides practical ideas on how to approach and plan for young learner courses as well as materials and ideas for specific activities. It will develop the awareness of what children aged 5 to 12 are capable of, what they enjoy and what strategies work best to motivate them to learn. In this course, the student will learn planning for young learner classes, it is about creating optimal conditions for learning, lesson planning, presenting and practicing language, using a course book, storytelling, games \& activities, projects based learning. Therefore, to make the interesting learning the researcher use Edmodo as educational social network to make the students enjoy the course because they use educational social network to get understand more. 
Based on the problems above, the aims of this research are to find out Edmodo can increase student's ability in learning course design of EYL and also student's perception in learning course design of EYL by using Edmodo.

\section{METHODOLOGY}

A mixed method was used to collect quantitative and qualitative data. It is a procedure for collecting, analyzing, and "mixing" both methods in a single study or a series of studies to understand a research problem (Creswell, 2002). In answering those two research questions, the researcher used test (pre-test and post-test) to collect quantitative data and also used interview as data gathering technique to collect qualitative data. In quantitative data, the researcher used a quasi-experiment method with one experiment class and one control class. The population of this research is the fifth semester students of university in Karawang, approximately 150 students. The sample of this research is 50 students. Those students were divided into two classes, 25 students in 5-D as controlled group and 25 students in 5-F as experimental group. The research instruments are test and guidance interview. Test was applied in experiment and controlled group to find score of students' achievement and guidance interview was categorized into 15 questions to know the student's perception in learning course design of EYL by using flipped classroom through Edmodo. The validity and reliability instrument test were conducted before the researcher administered the test to both classes. Before analyzing the hypotheses, the researcher had to analyze the normality of the data. This analysis is used to see whether the data got in the research normally distributed or not. The researcher used the SPSS V.16 for windows to test the normality and homogeneity tests. Next, the researcher used Independent T-test formula in SPSS V.16 to calculate the data. It is because the researcher wanted to find out the degree of significant different between the growth score of pre-test and post-test from both classes also between the achievement in experiment class and control class.

The validity and reliability instrument test was conducted before the researcher administered the test to both classes. There were 40 numbers of questions given to the 25 students of 5 -B of English education department in University of Singaperbangsa Karawang. From the validity and reliability test, there were 26 valid questions from 40 questions which were gained. 


\section{FINDINGS AND DISCUSSION}

\section{A. FINDINGS}

a. Edmodo can Increase Student's Ability in Learning Course Design of EYL

\begin{tabular}{|l|c|c|}
\hline \multicolumn{1}{|c|}{ Evaluation } & Experimental Class & Controlled Class \\
\hline Mean & 59.64 & 59.44 \\
Std. Error of Mean & 1.07994 & 1.09557 \\
Median & 60,00 & 60.00 \\
Mode & 60 & 55 \\
Std. Deviation & 5.399 & 5.477 \\
Variance & 29.157 & 30.007 \\
Range & 20.00 & 20.00 \\
Minimum & 50 & 50 \\
Maximum & 70 & 70 \\
Sum & 1491 & 1486 \\
\hline
\end{tabular}

Table 1 The Result of Pre-test (Experimental Class and Controlled Class)

Based on Table 1. Data description of pre-test there is no significant differences between experimental class and controlled class. It shown that mean of experimental class is 59.64 and controlled class is 59.44. Median of experimental class and controlled class is 60 . Standard deviation of experimental class is 5.399 and controlled class is 5.477. Score minimum of experimental class and controlled class is 50, and score maximum of experimental class and controlled class is 70 .

\begin{tabular}{|l|c|c|}
\hline \multicolumn{1}{|c|}{ Evaluation } & Experimental Class & Controlled Class \\
\hline Mean & 82.36 & 80.96 \\
Std. Error of Mean & 1.27525 & 1.39341 \\
Median & 85.00 & 80.00 \\
Mode & 85 & 85 \\
Std. Deviation & 6.376 & 6.967 \\
Variance & 40.657 & 48.540 \\
Range & 25.00 & 23.00 \\
Minimum & 70 & 70 \\
Maximum & 95 & 93 \\
Sum & 2059 & 2024 \\
\hline
\end{tabular}

Table 2 The Result of Post-test (Experimental Class and Controlled Class)

Based on Table 2. Data description of post-test there is significant differences between experimental class and controlled class. It shown that mean of experimental class is 
82.36 and controlled class is 80.96 . Median of experimental class is 85 and controlled class is 80. Standard deviation of experimental class is 6.376 and controlled class is 6.967. Score minimum of experimental class and controlled class is 70 , and score maximum of experimental class is 95 and controlled class is 93 .

\begin{tabular}{|c|c|c|c|c|c|c|}
\hline \multirow{2}{*}{ Group } & \multicolumn{3}{|c|}{ Pre-Test } & \multicolumn{3}{c|}{ Post-Test } \\
\cline { 2 - 7 } & \multicolumn{3}{|c|}{ Shapiro-Wilk } & \multicolumn{3}{c|}{ Shapiro-Wilk } \\
\cline { 2 - 7 } & Statistic & Df & Sig. & Statistic & Df & Sig. \\
\hline Control Class & .923 & 25 & .061 & 922 & 25 & .056 \\
\hline Experimental Class & .928 & 25 & .077 & 941 & 25 & .155 \\
\hline
\end{tabular}

Table 3 Normality Test (Experimental Class and Controlled Class)

From the Table 3. Normality Test, the result of pre-test and post-test between Experimental Class and Controlled Class shown that the data are normally distributed. It can be seen Sig. pre-test of experimental class is higher than $0.05(0.077>0.05)$, and the sig. pretest of controlled class is also higher than $0.05(0.061>0.05)$. Meanwhile, Sig. post-test of experimental class is higher than $0.05(0.155>0,05)$ and also Sig, post-test of controlled class is higher than $0.05(0.56>055)$.

\begin{tabular}{|c|c|c|c|c|c|c|c|}
\hline Levene & \multicolumn{3}{|c|}{ Pre-Test } & Levene & \multicolumn{3}{|c|}{ Post-Test } \\
\hline Statistic & df1 & df2 & Sig. & Statistic & df1 & $\mathrm{df} 2$ & Sig. \\
\hline .052 & 1 & 48 & .821 & .565 & 1 & 48 & .456 \\
\hline
\end{tabular}

Table 4 Homogeneity Test (Experimental Class and Controlled Class)

From the Table 4. Homogeneity Test, the result of pre-test and post-test shown that there is no significant difference between experimental class and controlled class. It can be seen Sig. of homogeneity pre-test between experimental class and controlled class is higher than $0.05(0.821>0.05)$. Meanwhile, Sig. of homogeneity post-test between experimental class and controlled class is higher than $0.05(0.456>0,05)$.

The last calculation was testing the hypotheses. This was the crucial calculation to answer the problem formulation of this research that whether there is significant difference between students' understanding using "Edmodo" and students' understanding in controlled class which were not. The researcher used SPSS v.16 for windows program which is Independent T-Test. The criteria for hypothesis test are:

If the significance ( 2 tailed) $<0.05$ the $\mathrm{H}_{0}$ is accepted

If the significance (2 tailed) $>0.05 \mathrm{H}_{0}$ is rejected or $\mathrm{H}_{\mathrm{a}}$ is accepted 
The table below showed the result between the experimental class which were given "Edmodo" and the controlled class which were not given "Edmodo".

\begin{tabular}{|c|c|c|c|c|c|c|c|c|c|c|}
\hline & \multicolumn{2}{|c|}{\begin{tabular}{|lrr} 
Levene's & Test & for \\
Equality & & of \\
Variances & &
\end{tabular}} & \multicolumn{7}{|c|}{ t-test for Equality of Means } \\
\hline & & \multirow[b]{2}{*}{$\mathrm{F}$} & \multirow[b]{2}{*}{ Sig. } & \multirow[b]{2}{*}{$\mathrm{T}$} & \multirow[b]{2}{*}{ Df } & \multirow{2}{*}{$\mid \begin{array}{l}\text { Sig. (2- } \\
\text { tailed) }\end{array}$} & \multirow{2}{*}{$\begin{array}{l}\text { Mean } \\
\text { Difference }\end{array}$} & \multirow{2}{*}{$\begin{array}{l}\text { Std. Error } \\
\text { Difference }\end{array}$} & $\begin{array}{l}95 \% \\
\text { Interval } \\
\text { Difference }\end{array}$ & $\begin{array}{l}\text { Confidence } \\
\text { of the }\end{array}$ \\
\hline & & & & & & & & & Lower & Upper \\
\hline Score & $\begin{array}{l}\text { Equal variances } \\
\text { assumed }\end{array}$ & .565 & .456 & -.741 & 48 & .462 & -1.400 & 1.889 & -5.198 & 2.398 \\
\hline & $\begin{array}{l}\text { Equal variances } \\
\text { not assumed }\end{array}$ & & & & 47.628 & .462 & -1.400 & 1.889 & -5.199 & 2.399 \\
\hline
\end{tabular}

Table 5 Independent Samples Test (Post-test Experimental and Control Group)

From Table 5. Independent Sample t-test (Post-test of Experimental and Control Group) above, it showed that the score of significance value is 0.462 while the score of degree of significance is 0.05 . It means that significance value (sig. 2-tailed) was higher than degree of significance. Moreover, $\mathrm{H}_{0}$ is rejected while $\mathrm{H}_{\mathrm{a}}$ is accepted. It would be concluded that there is significant difference of students' score between the experimental class which were given "Edmodo"and the controlled class which were not given "Edmodo". In other word, the flipped classroom through Edmodo can increase student's ability in learning Course Design of EYL.

\section{A. Student's Perception in Learning Course Design of EYL by Using Edmodo}

In this study, the researcher used questionnaires with a checklist form; the respondents gave the check mark $(\sqrt{ })$ in the available space. This questionnaire consists of 15 statements were only given to the experimental group. The following is the results of the questionnaires:

1. Pembelajaran EYL dengan memanfaatkan aplikasi Edmodo menarik bagi saya

\begin{tabular}{|l|c|c|}
\hline & Frequency & Percent \\
\hline Strongly Disagree & 1 & 4.0 \\
Disagree & 2 & 8.0 \\
\hline
\end{tabular}




\begin{tabular}{|l|c|c|} 
Agree & 16 & 64.0 \\
Strongly Agree & 6 & 24.0 \\
Total & 25 & 100.0 \\
\hline
\end{tabular}

Table 6 Calculation Result of Item Number 1 in Questionnaire

Based on the Table 6. Calculation Result of Item Number 1 in Questionnaire, it can be seen that 16 of the 25 students (64\%) Agree and $24 \%$ strongly Agree about the statement. It can be concluded that the student agree that utilizing Edmodo is interest in learning EYL.

2. Pembelajaran dengan aplikasi Edmodo membuat saya lebih mudah memahami materi EYL

\begin{tabular}{|l|c|c|}
\hline & Frequency & Percent \\
\hline Strongly Agree & 5 & 20.0 \\
Agree & 18 & 72.0 \\
Disagree & 2 & 8.0 \\
Total & 25 & 100.0 \\
\hline
\end{tabular}

Table 7 Calculation Result of Item Number 2 in Questionnaire

From the Table 7. Calculation Result of Item Number 2 in Questionnaire, it can be seen that 18 of the 25 students (72\%) Agree, and 5 of the 25 students (20\%) Strongly agree that they get easy to understand the material of EYL subject. It can be concluded that the students agree that they can understand the material by using Edmodo.

3. Saya merasa senang dengan pembelajaran yang memanfaatkan aplikasi Edmodo sebagai media pembelajaran dalam mata kuliah Course Design of EYL

\begin{tabular}{|l|c|c|}
\hline & Frequency & Percent \\
\hline Agree & 19 & 76.0 \\
Strongly Agree & 6 & 24.0 \\
Total & 25 & 100.0 \\
\hline
\end{tabular}

Table 8 Calculation Result of Item Number 3 in Questionnaire

From the Table 8. Calculation Result of Item Number 3 in Questionnaire, it can be seen that 19 of the 25 students (76\%) agree, and 6 of the 25 students (24\%) Strongly agree about the statement. 
Thus, it can be concluded that most of the students agree that they are happy in learning course design of EYL by using Edmodo.

4. Pembelajaran EYL dengan memanfaatkan Edmodo membuat saya dapat saling bertukar pendapat antar teman sebaya

\begin{tabular}{|l|c|c|}
\hline & Frequency & Percent \\
\hline Disagree & 1 & 4.0 \\
Strongly Agree & 19 & 76.0 \\
Agree & 5 & 20.0 \\
Total & 25 & 100.0 \\
\hline
\end{tabular}

Table 9 Calculation Result of Item Number 4 in Questionnaire

Based on the table Table 9. Calculation Result of Item Number 4 in Questionnaire, it can be seen that 19 of the 25 students $(76 \%)$ strongly agree, 5 of the 25 students (20\%) agree and 1 of the 25 students (4\%) disagree about the statement. Thus, it can be concluded that most of the students agree that using Edmodo can help them easier to get peer feedback.

5. Saya dapat menambah wawasan mengenai materi EYL ketika memanfaatkan Edmodo sebagai media pembelajaran

\begin{tabular}{|l|c|c|}
\hline & Frequency & Percent \\
\hline Disagree & 11 & 44.0 \\
Agree & 14 & 56.0 \\
Total & 25 & 100.0 \\
\hline
\end{tabular}

Table 10 Calculation Result of Item Number 5 in Questionnaire

From the table Table 10. Calculation Result of Item Number 5 in Questionnaire, it can be seen that 14 of the 25 students (56\%) agree and 11 of the 25 students (44\%) Disagree. Thus, it can be concluded that a half of the students agree that Edmodo can give more information about the material Course design of EYL. 
6. Pembelajaran dengan memanfaatkan Edmodo membuat saya berani mengungkapkan pendapat dalam diskusi

\begin{tabular}{|l|c|c|}
\hline & Frequency & Percent \\
\hline Agree & 20 & 80.0 \\
Strongly Agree & 5 & 20.0 \\
Total & 25 & 100.0 \\
\hline
\end{tabular}

Table 11 Calculation Result of Item Number 6 in Questionnaire

Based on the Table 11. Calculation Result of Item Number 6 in Questionnaire, it can be seen 20 of 25 students (80\%) Agree with the statement number 6 , while 5 of 25 students (20\%) Strongly agrees. Thus, it can be conclude the student agree that they are more confident to express an idea in discuss Course Design of EYL by using Edmodo.

7. Rangkuman yang di Posting melalui Edmodo membuat saya dapat memahami isi materi EYL tersebut

\begin{tabular}{|l|c|c|}
\hline & Frequency & Percent \\
\hline Agree & 8 & 32.0 \\
Strongly Agree & 17 & 68.0 \\
Total & 25 & 100.0 \\
\hline
\end{tabular}

Table 12 Calculation Result of Item Number 7 in Questionnaire

Based on the Table 12. Calculation Result of Item Number 7 in Questionnaire, it can be seen 17 of 25 students (68\%) strongly agree with the statement number 7 , while 8 of 25 students $(32 \%)$ agrees. Thus, it can be conclude that the most of student strongly agree that they can understand the material Course Design of EYL that had posted in Edmodo.

8. Kesempatan berdiskusi dengan teman satu kelompok atau teman satu kelas memudahkan saya dalam memahai materi EYL

\begin{tabular}{|l|c|c|}
\hline & Frequency & Percent \\
\hline Agree & 24 & 96.0 \\
Strong Agree & 1 & 4.0 \\
Total & 25 & 100.0 \\
\hline
\end{tabular}

Table 13 Calculation Result of Item Number 8 in Questionnaire 
From the Table 13. Calculation Result of Item Number 8 in Questionnaire, it can be seen more than half of the students Agree (96\%) with the statement above, while 1 of 25 students (4\%) Strongly Agree. Thus, it can be conclude, almost all of the students agree that they are easier to understand the material Course Design of EYL because they can discuss with the other in the group class.

9. Saya merasa tidak senang pada saat pembelajaran EYL dilakukan dengan memanfaatkan Edmodo

\begin{tabular}{|l|c|c|}
\hline & Frequency & Percent \\
\hline Agree & 8 & 32.0 \\
Disagree & 17 & 68.0 \\
Total & 25 & 100.0 \\
\hline
\end{tabular}

\section{Table 14 Calculation Result of Item Number 9 in Questionnaire}

From the Table 14. Calculation Result of Item Number 9 in Questionnaire, it shown 17 students of 25 disagree (68\%) with the statement number 9 , while 8 of 25 students (32\%) agree. Thus, it can be conclude almost all of the students disagree that they are unhappy in utilize Edmodo in learning Course Design of EYL.

10.Pembelajaran dengan menggunakan Edmodo dirasa kurang efektif dalam proses belajar mengaajar di kelas

\begin{tabular}{|l|c|c|}
\hline & Frequency & Percent \\
\hline Agree & 11 & 44.0 \\
Disagree & 14 & 56.0 \\
Total & 25 & 100.0 \\
\hline
\end{tabular}

Table 15 Calculation Result of Item Number 10 in Questionnaire

From the Table 15. Calculation Result of Item Number 10 in Questionnaire, it shown a half of the students disagree (56\%) with the statement, while 11 of 25 students (44\%) agree. However, it can be conclude almost a half of the students disagree that Edmodo are not effective in learning process Course Design of EYL. 
11. Saya lebih senang pembelajaran EYL melalui Edmodo dibandingkan dengan media sebelumnya

\begin{tabular}{|l|c|c|}
\hline & Frequency & Percent \\
\hline Disagree & 4 & 16.0 \\
Strongly agree & 10 & 40.0 \\
Agree & 7 & 28.0 \\
Strongly disagree & 4 & 16.0 \\
Total & 25 & 100.0 \\
\hline
\end{tabular}

Table 16 Calculation Result of Item Number 11 in Questionnaire

From the Table 16. Calculation Result of Item Number 11 in Questionnaire, it shown more than half of the students strongly agree (40\%) with the statement, while 4 of 25 students (16\%) strongly disagree and 4 of 25 students (16\%) disagree and 7 of 25 is agree. Thus, it can be conclude almost all of the students agree that Edmodo is a better learning media in learning process Course Design of EYL.

12.Saya merasa lebih aktif dalam pembelajaran EYL ketika memanfaatkan Edmodo sebagai media pembelajaran di kelas

\begin{tabular}{|l|c|c|}
\hline & Frequency & Percent \\
\hline Strongly Agree & 5 & 20.0 \\
Agree & 10 & 40.0 \\
Disagree & 6 & 24.0 \\
Strongly Disagree & 4 & 16.0 \\
Total & 25 & 100.0 \\
\hline
\end{tabular}

Table 17 Calculation Result of Item Number 12 in Questionnaire

Based on the Table 17. Calculation Result of Item Number 12 in Questionnaire, it shown more than half of the students agree (40\%) with the statement number 12, while 5 of 25 students (20\%) Strongly agree and 6 of 25 students (24\%) disagree, then 4 of 25 students (16\%) strongly disagree. Therefore, it can be conclude almost a half of the 
students agree that they feel more active in learning Course Design of EYL when utilize Edmodo as learning media.

13. Saya dapat melatih diri untuk menghargai pendapat orang lain dalam kegiatan diskusi

\begin{tabular}{|l|c|c|}
\hline & Frequency & Percent \\
\hline Agree & 20 & 80.0 \\
Strongly Agree & 5 & 20.0 \\
Total & 25 & 100.0 \\
\hline
\end{tabular}

Table 18 Calculation Result of Item Number 13 in Questionnaire

From the Table 18. Calculation Result of Item Number 13 in Questionnaire, it shown the most of the 25 students agree (80\%) with the statement, while 5 of 25 students (20\%) Strongly agree. Thus, it can be conclude that all of the students agree that they can respect with the idea of their friends when discuss.

14. Saya dapat membuat simpulan dari pembahasan materi yang telah dipresentasikan

\begin{tabular}{|l|c|c|}
\hline & Frequency & Percent \\
\hline Agree & 7 & 28.0 \\
Strongly Agree & 18 & 72.0 \\
Total & 25 & 100.0 \\
\hline
\end{tabular}

Table 19 Calculation Result of Item Number 14 in Questionnaire

Based on the Table 19. Calculation Result of Item Number 14 in Questionnaire, it shown that almost of the students strongly agree (72\%) with the statement and 7 of 28 students (28\%) agree. Therefore, it can be conclude that all of the students agree that they can make summary of the material Course Design of EYL that has discussed in the class 
15.Pemanfaatan Edmodo dalam pembelajaran EYL membuat saya dapat mempersiapkan materi EYL yang akan didiskusikan

\begin{tabular}{|l|r|r|}
\hline & Frequency & Percent \\
\hline Agree & 22 & 88.0 \\
Strongly Agree & 3 & 12.0 \\
Total & 25 & 100.0 \\
\hline
\end{tabular}

Table 20 Calculation Result of Item Number 15 in Questionnaire

From the table 20. Calculation Result of Item Number 15 in Questionnaire, it shown that almost the students agree (88\%) with the statement and 3 of 25 students (12\%) Strongly agree. Thus, it can be conclude all of the students agree that utilize Edmodo in learning Course Design of EYL can make them are easy in prepare the material that will be discuss.

\section{B. DISCUSSION}

\section{Edmodo can Increase Student's Ability in Learning Course Design of EYL}

From the data above showed that the score of significance value of independent T-Test is 0.462 while the score of degree of significance is 0.05 . It meant that significance value (sig. 2-tailed) was higher than degree of significance $0.462>0.05$.. Moreover, $\mathrm{H}_{0}$ is rejected while $\mathrm{H}_{\mathrm{a}}$ is accepted. It would be concluded that there is significant difference of students' score between the experimental class and the controlled class.

The researcher choose $\mathrm{V}-\mathrm{F}$ as the experimental class which got treatment using "Edmodo" and V-D as the controlled class which did not get "Edmodo". The treatment was given four-week term with one meetings per week in an English Course Design of EYL class of fifth semesters students at English Education Department in University of Singaperbangsa Karawang. In the experimental class, the mean of pre-test is 59.64, that mean of pre-test in the controlled class is 59.44 and that of gain score is only 0,20. After the treatment was given, the researcher gave the post-test and the result was the score of experimental class is higher than the controlled class. It can be seen from the mean of post-test in the experimental class is 82.36 , that mean of post-test in the controlled class is 80.96. The gain score is 1,40 . In other words, the use of social media Edmodo can increase the students' ability in learning Course Design of EYL. 


\section{The Students' perception in learning course design of EYL by using Edmodo}

Questionnaires aim to determine the students' perception in learning course design of EYL by using Edmodo in experimental group. Based on the calculation, it can be interpreted from the 15 item questionnaire, specifically: (1) The student agree that utilizing edmodo is interest in learning EYL. (2) The students agree that they can understand the material by using Edmodo. (3) Most of the students agree that they are happy in learning by using Edmodo. (4) Most of the students agree that using edmodo can help them easier to get peer feedback. (5) A half of the students agree that edmodo can give more information about the material Course design of EYL. (6) The student agree that they are more confident to express an idea in discuss Course Design of EYL by using edmodo. (7) Most of student strongly agree that they can understand the material Course Design of EYL that had posted in Edmodo. (8) Almost all of the students agree that they are easier to understand the material Course Design of EYL because they can discuss with the other friends in the group class. (9) Almost all of the students disagree that they are unhappy to utilize edmodo in learning Course Design of EYL. (10) Almost a half of the students disagree that edmodo are not effective in learning process Course Design of EYL. (11) Almost all of the students agree that edmodo is a better learning media in learning process Course Design of EYL. (12) Almost a half of the students agree that they feel more active in learning Course Design of EYL when utilize edmodo as learning media. (13) All of the students agree that they can respect with the idea of their friends when discuss. (14) All of the students agree that they can make summary of the material Course Design of EYL that has discussed in the class (15) All of the students agree that utilize Edmodo in learning Course Design of EYL can make them are easy in prepare the material that will be discuss.

From the interpretation of each items above, it can be concluded that the students' interest and provide a positive responses to learnt Course Design of EYL by using Edmodo. 


\section{CONCLUSION}

Based on the result of the research finding, the researcher drew a conclusion that Edmodo can increase student's ability in learning Course Design of EYL. It is proven by the score of Independent T-test $-0,741$ and sig (2 tailed) was higher than degree of significance $(0,462<0,05)$. Then, student's perception in learning course design of EYL by using Edmodo showed that Edmodo can help more understand the materials because they can get more information about materials Course Design of EYL they can discuss the materials each other anywhere and anytime, they felt more interesting and happy, they are more confident to express their ideas, moreover they can be more active in learning course design of EYL. Therefore, the use of edmodo is one of joyful alternative teaching to support the creative teachers. It is recommended for English Teacher or lecture to use Edmodo as alternative media to improve quality of teaching. 


\section{BIBLIOGRAPHY}

Basal, A. 2015. The Implementation of A Flipped Classroom in Foreign Language Teaching. Yildiz Technical University. Turkey.

Cauley, P. 2012. A guide to Explain it all. Retrieved from IT Babble.com

Creswell, J. W. 2012. Educational Research (Planning, Conducting and Evaluating Quantitative and Qualitative Research). Boston: Pearson Education.

Evenddy, S. S \& Hamer, W. 2016. Edmodo As Media to Teach Vocabulary. The Journal of English Language Studies.

Graves, K. 2000. Designing Language Courses: A Guide for Teachers. (D. Freeman, Ed.) Boston: Heinle Cengage Learning.

Monalisa and Ardi, H. 2013. Using "Edmodo" Educational Social Network in Teaching English For High School Students. English Department of FBS UNP. Padang.

Prasetya, C. 2011. Teaching English for Young Learners. Retrieved from https://cicikprasetya.wordpress.com/2011/08/29/teaching-english-for-young-learners/

Press Page. Edmodo. Retrieved from http://edmodo.com/

Suyanto, K. K.E. 2007. English For Young Learners. PT Bumi Aksara: Jakarta.

Thompson, H. 2013. The Edmodo Quick Start Guide. 